\title{
Peroxisome proliferator-activated receptor subtypes in mammary gland development and breast cancer
}

\author{
Caitlin Falconer ${ }^{1}$, Paraic A. Kenny ${ }^{2}$, Chanel E. Smart ${ }^{3}$, Gregory R Monteith ${ }^{1}$ and Sarah J Roberts-Thomson ${ }^{1 *}$
}

\begin{abstract}
Background: Peroxisome proliferator-activated receptors (PPARs) have a pivotal role in regulating genes that are involved in lipid homeostasis.

Methods: We examined the mouse mammary gland during different developmental stages and assessed the relative expression of PPARs. We also examined the expression of PPARs in breast cell lines and tumors.

Results: Each isoform was detected at all stages of mammary gland development but the relative profile of each isoform differed between glands from animals that were nulliparous, pregnant, lactating or involuting. PPARa and PPAR $\gamma$ were highest in glands from nulliparous animals, whereas PPAR $/ \delta$ was highest in glands from pregnant mice. Since many tumors are also characterized by changes in lipid profile we examined the expression of PPARs in breast cell lines and tumors. PPARa expression was higher in basal breast cancers and high expression levels were associated with reduced human breast cancer patient survival, whereas PPARY expression did not differ between breast cancer subtypes. PPAR $\beta / \delta$ expression was upregulated in breast tumors of the basal and HER2 enriched breast cancer subtypes and intermediate and high levels of PPAR $\beta / \delta$ expression were associated with a poor outcome for breast cancer patient survival.
\end{abstract}

Conclusion: These results show that the profile of PPAR isoform expression changes with mammary gland morphological and functional development and maybe important in breast tumorigenesis.

Keywords: PPAR, Breast, Mammary gland, Cancer, Lipid

\section{Introduction}

Peroxisome proliferator-activated receptors (PPARs) are ligand activated transcription factors that are members of the nuclear hormone receptor superfamily [1]. There are three members of this subfamily, PPARa, PPAR $\beta / \delta$ and PPAR $\gamma$ with each subtype having overlapping but distinct tissue distribution [1]. PPARa is primarily expressed in tissues involved with fatty acid catabolism, e.g. liver, kidney, skeletal muscle, brown adipose tissue and heart, whereas PPAR $\beta / \delta$ is widely expressed and found in most tissues dependent on the stage of cell differentiation and proliferation. PPARY is predominantly found in adipose, liver, kidney, gut, brain and vascular tissues $[\mathbf{1 , 2}]$. The genes regulated by these transcription factors are involved in many different processes including cell cycle, differentiation and inflammation [1]. However, one of the main roles of these subtypes is their involvement in lipid homeostasis [3]. PPARa transcriptionally activates genes that control fatty acid catabolism [4], PPAR $\beta / \delta$ has a prominent role in fatty acid oxidation [5] and PPARY activates genes that function in adipogenesis [6].

The mammary gland is an organ that undergoes distinct developmental stages post-birth under the influence of hormones [7]. The basic glandular network is established during

\footnotetext{
Correspondence: sarahrt@uq.edu.au

${ }^{1}$ School of Pharmacy, The University of Queensland, Brisbane, Queensland, Australia .

Full list of author information is available at the end of the article
}

puberty, but the onset of pregnancy marks the beginning of changes toward functional differentiation. The mammary epithelial cells proliferate and give rise to a branching network of ducts and alveoli. At the end of pregnancy and during lactation the alveolar epithelium becomes secretory and produces milk [7]. Finally after lactation ceases the mammary gland involutes, a stage that is characterized by a remodelling of the gland to produce a more rudimentary structure in a process involving apoptosis followed by remodeling of stroma and re-differentiation of adipocytes [8].

Breast milk is rich in lipids, the precise percentage is species dependent but ranges from $4 \%$ in humans to $50 \%$ in whales [9]. In mice, the lipid content of milk is approximately $30 \%$, resulting in the secretion of approximately $30 \mathrm{~g}$ of lipid over a 20 day lactation period [10]. The major milk lipid is triacyclglyceride, which comprises $98 \%$ of the total milk lipid [9]. Enzymes to synthesize lipids de novo increase in expression within the mammary gland at lactation [11]. Given the role of the PPARs in cellular processes including differentiation and lipid homeostasis, their expression in the mammary gland during different stages of development may give some insight into the processes that control lipid biosynthesis in the mammary gland. Understanding the normal physiology of the gland is important in determining changes that may be deregulated in pathophysiological states. We have shown previously that a calcium transporter, known as SPCA2, is important during lactation [12] and is also upregulated in breast cancer cells 
and human breast tumors [13].

Many tumors are characterized by alterations in lipid homeostasis with concomitant changes in the expression and activity of many lipogenic and lipolytic enzymes. Many of these changes occur in enzymes regulated by PPARs $[14,15]$. PPAR subtypes are linked with tumorigenic processes in breast cancer cells including actions that are both pro- and anti-tumorigenic through differential effects on cellular proliferation, apoptosis and differentiation [14]. Given their role in lipid homeostasis, their effects are likely to extend to influencing the balance of lipids within a tumor and specifically their relationship with breast cancer could depend on the molecular profile of the tumor itself. Breast cancer is stratified into transcriptionally different subtypes based on gene expression patterns and includes subtypes described as basal-like, ERBB2 (HER2)enriched, luminal $A$ and luminal $B$ [16]. A potential association between specific PPAR subtypes and breast cancer subtypes is suggested by the regulation of PPARy expression and cellular response by HER2 [17].

Our aim with this study was to explore the expression of the PPARs in physiological and pathophysiological states of the mammary gland, i.e. mammary gland development and breast cancer and assess possible relationships between PPAR subtype expression and breast cancer prognosis.

\section{Methods}

\section{Tissue samples and cell culture}

Mammary glands were isolated from CBA x C57BI6 mice [12]. Nulliparous animals were euthanized at 14 weeks of age. Other stages of mammary gland development included midpregnancy ( day 10$)$, lactation (day 1$)$ and involution (48 $\mathrm{h}$ post-forced weaning). Culture conditions for the tumorigenic breast cancer cell lines MCF-7, MDA-MB-231, BT-483, SK-BR-3, T-47D, ZR-75-1 and non-tumorigenic breast cancer cell lines $184 \mathrm{~A} 1$ and 184B5 are described in Lee et al. [18].

\section{RNA isolation and real time RT-PCR}

RNA was isolated and amplified using real time RT-PCR as described in Aung et al [19] and the following Taqman Gene Expression assays (Applied Biosystems, Scoresby, Vic., Australia): mouse Ppara, Mm00440939_m1; mouse Ppard, Mm1305434_m1; mouse Pparg, Mm01184322_m1; human PPARa, Hs00947537_m1; human PPARß/ס, Hs00602622_m1; human PPARY, Hs001115513_m1 and 18S rRNA assay reagent (4319413E). Real time RT-PCR results were analyzed for statistical significance using a one-way ANOVA with Tukey's post-test (GraphPad Prism, GraphPad Software, San Diego, California, USA). Significance is indicated in the results.

\section{Microarray analysis}

PPAR gene expression was assessed in breast cancer clinical samples in the NKI-295 dataset consisting of the microarray profiles of 295 primary breast tumors [20]. Raw data are available from the NCBI Gene Expression Omnibus (Accession number: GSE2845). Tumors were assigned to molecular subtypes based on their gene expression profiles and those matching to the basal-Like, HER2-overexpressing, luminal $A$ and luminal B subtypes were analysed for PPAR gene expression. Samples matching to the "Normal-Like" subtype were excluded from the analysis as these are believed to be substantially contaminated by normal tissue. Kaplan-Meier analysis was used to determine correlation of PPAR gene expression with patient survival and statistical significance was assessed using the log-rank test.

\section{Results and Discussion}

The requirement of the mammary gland for lipid metabolism alters with the developmental stage of the gland, particularly during the transition from a pregnant to a lactating gland in preparation for delivering nutrients to the new born [21]. Examining the profile of PPAR subtype expression with the morphological and physiological changes of the gland may promote a better understanding of lipid homeostasis.

As the structure and function of the mammary gland changed with pregnancy, lactation and finally early involution, the profile of each PPAR also altered, although each subtype was detectable at all mammary gland stages (Figure 1) as described earlier in other studies $[\mathbf{2 1}, \mathbf{2 2}, \mathbf{2 3}, \mathbf{2 4}, \mathbf{2 5}]$. While our work did not focus on protein levels, the relative levels of PPARa mRNA transcripts were significantly $(P<0.05)$ highest in the nulliparous gland (Figure 1A), whereas PPAR $\beta / \delta$ 's expression was increased significantly $(P<0.05)$ upon pregnancy before falling again once lactation had started (Figure 1B). PPAR $y$ expression significantly $(P<0.05)$ dropped with pregnancy, but then continued to significantly decrease $(P<0.05)$ beginning with early lactation (Figure 1C). Comparing the relative levels of each subtype suggested that PPAR $\gamma$ was the principal subtype expressed in the nulliparous mammary gland (Figure 2A), whereas in the pregnant gland the relative level of PPAR $\beta / \delta$ had increased so that the gland had equivalent levels of PPAR $\beta / \delta$ and PPAR $\gamma$ (Figure 2B). The relative levels of PPAR $\beta / \delta$ and PPAR $\gamma$ remained high compared with PPARa during both lactation and involution (Figure 2C \& 2D).

Since PPARa is pivotal in controlling genes important in the $\beta$-oxidation of fatty acids [4], it is not surprising that its expression level would decrease during the transition of the animal from pregnancy to lactation. The secretory phase of the animal is the time during which the production of milk for the neonate becomes foremost [21] and so the gland moves towards supporting lipogenesis and away from $\beta$-oxidation $[21,26]$. Studies with a transgenic mouse harboring a constitutively active PPARa show that PPARa activation during pregnancy results in a severe defect in lobuloalveolar development via a reduction in proliferation and an increase in apoptosis [27]. This effect of activated PPARa suggests a physiological reason why PPARa decreases in expression between the nulliparous and pregnant animal. 


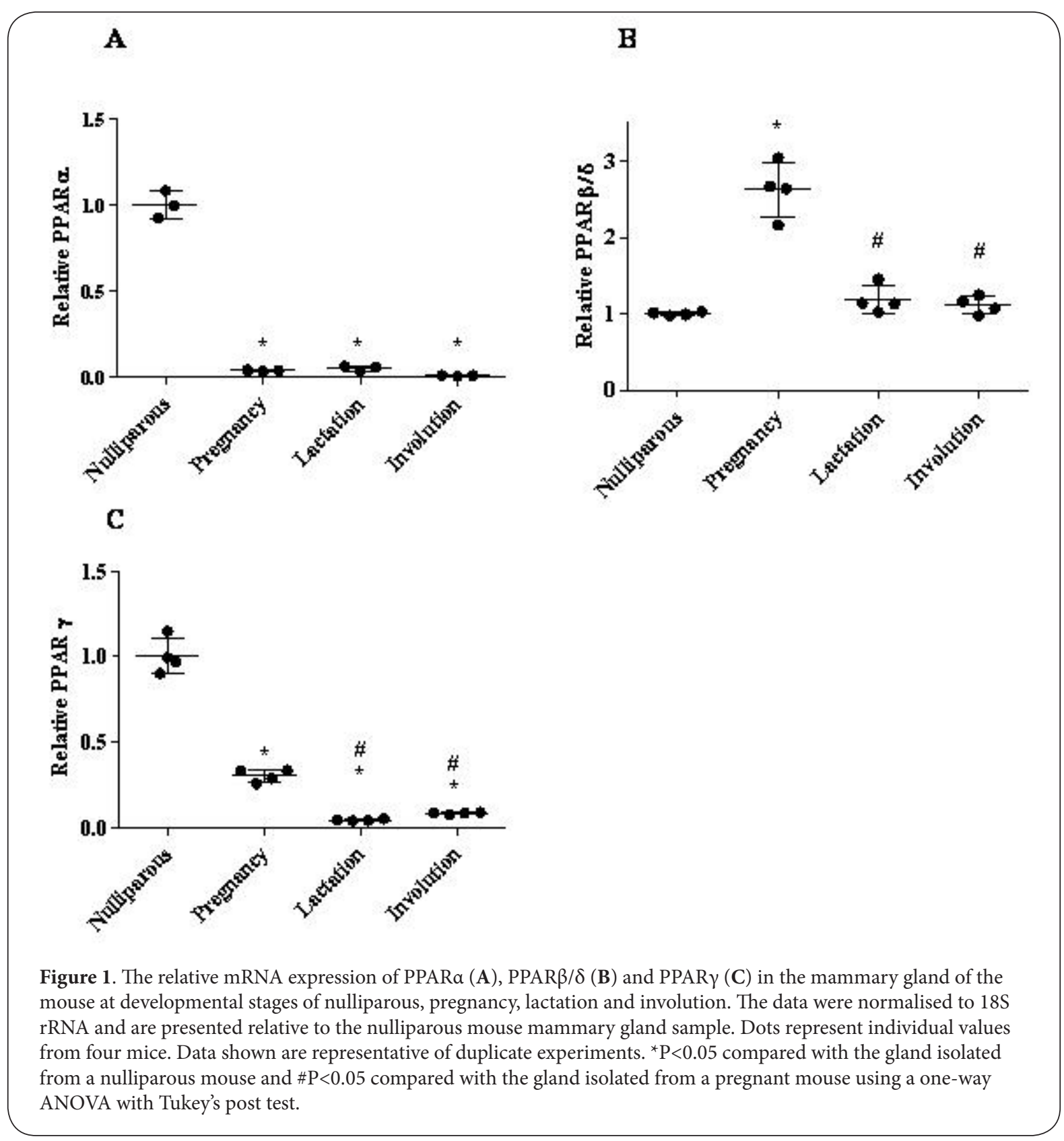

There is a paucity of data on the role of PPAR $\beta / \delta$ in the mammary gland. Other studies have reported no change in PPAR $\beta / \delta$ with differentiation of the gland, however, these studies did not use real time PCR quantitative methods $[23,28]$. Our study suggests that the relative level of PPAR $\beta / \delta$ becomes more important once the gland begins to develop during pregnancy, highlighting a potentially important role for this transcription factor in regulating cell proliferation, differentiation and survival at this time in mammary gland development. PPAR $\gamma$ has a well-defined role in adipose tissue involving differentiation and promoting lipid storage [6].
One suggestion is that a decrease in PPARy during mammary gland differentiation is fundamental to a switch of the gland's activities from $\beta$-oxidation to lipogenesis [21]. Interestingly, however, the role of PPARY in the lactating mammary gland has been proposed to be important in maintaining the quality of milk by ensuring inflammatory lipids in the milk are not accumulating [29]. In our study using whole mammary glands, the alterations in PPARs may be in part related to a decreasing adipocyte contribution and increasing epithelial cell contribution to the gland architecture. 


\section{A: Nulliparaus}

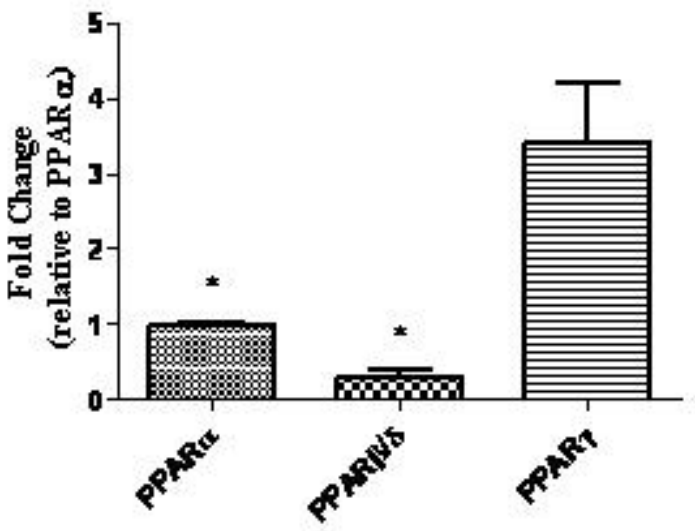

c: Lactation

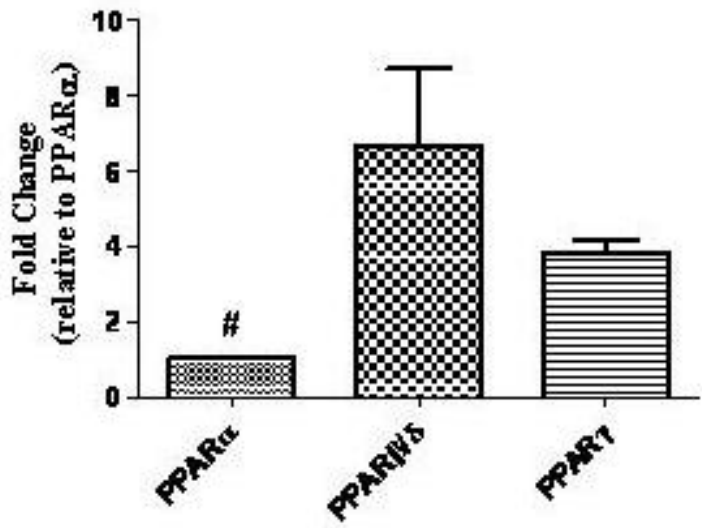

B: Pregrancy

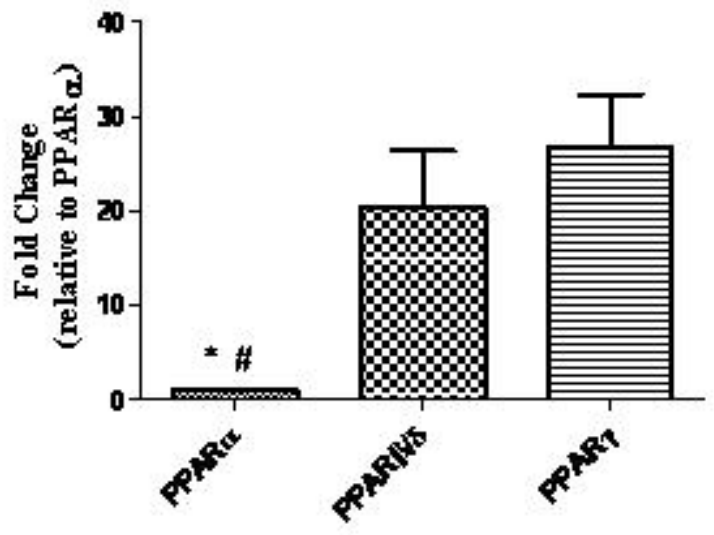

D: Irwalution

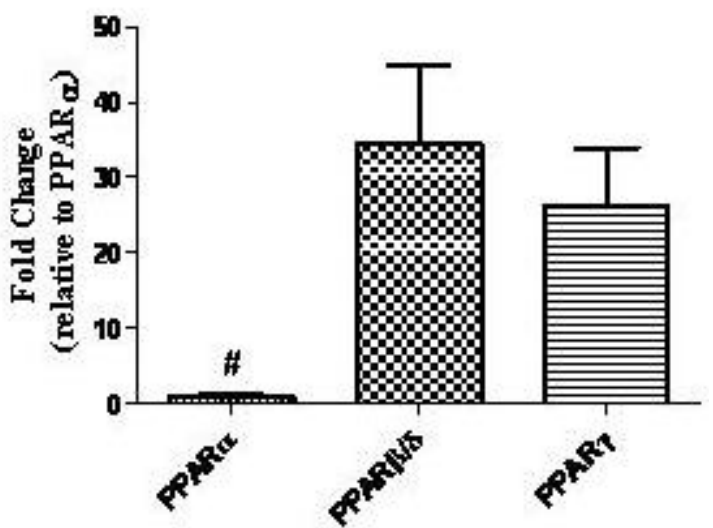

Figure 2. The relative mRNA expression of PPAR subtypes at each stage of mouse mammary gland development: nulliparous (A), pregnancy (B), lactation (C) and involution (D). Data are fold change normalised to 18S rRNA and are presented relative to PPARa. Each bar represents the mean calculated from 4 mice assessed in duplicate \pm S.E.M. $(\mathrm{n}=8) .{ }^{*} \mathrm{P}<0.05$ compared with PPAR $\gamma$ and $\# \mathrm{P}<0.05$ compared with $\mathrm{PPAR} \beta / \delta$, using a one-way ANOVA with Tukey's post test.

Our study looking at the profile of PPAR subtype expression in a panel of breast cancer cell lines showed a lack of correlation between tumorigenicity and expression of individual subtypes (Figure 3), which is consistent with a previous study involving a smaller cohort of breast cancer cell lines [30]. Expression of both PPAR $\beta / \delta$ and PPAR $\gamma$ was highest in the MDA-MB-231 breast cell line compared with the tested non-tumorigenic and breast cancer derived cell lines (Figure 3B \& 3C). MDA-MB-231 cells also had the highest expression of PPARa compared with the other tumorigenic breast cancer cell lines examined (Figure 3A) [31]. Further work examining knockdown of PPAR subtypes in MDAMB-231 cells with a focus on functional outcomes such as cell proliferation and apoptosis will provide more information on the role of the PPARs in breast cancer cells. MDA-MB-231 cells are estrogen receptor negative and are used experimentally as a model of basal-like breast cancer [32]. PPARy expression has been linked to a stellate morphology, which occurs when MDA-MB-231 cells are grown in three-dimensions, and is indicative of a subset of breast cancers referred to as having a triple-negative status [33]. Basal-like breast cancers (identified by gene expression profiling) and triple-negative breast cancers (identified by immunohistochemical staining for a lack of ER, PR and HER2) while not being identical do have some overlapping features including a poor prognosis [34]. Our results suggested a possible delineation of PPAR subtype expression with certain subtypes of breast cancers leading us to examine the expression of PPARs in a large cohort of human breast cancer tumors. 


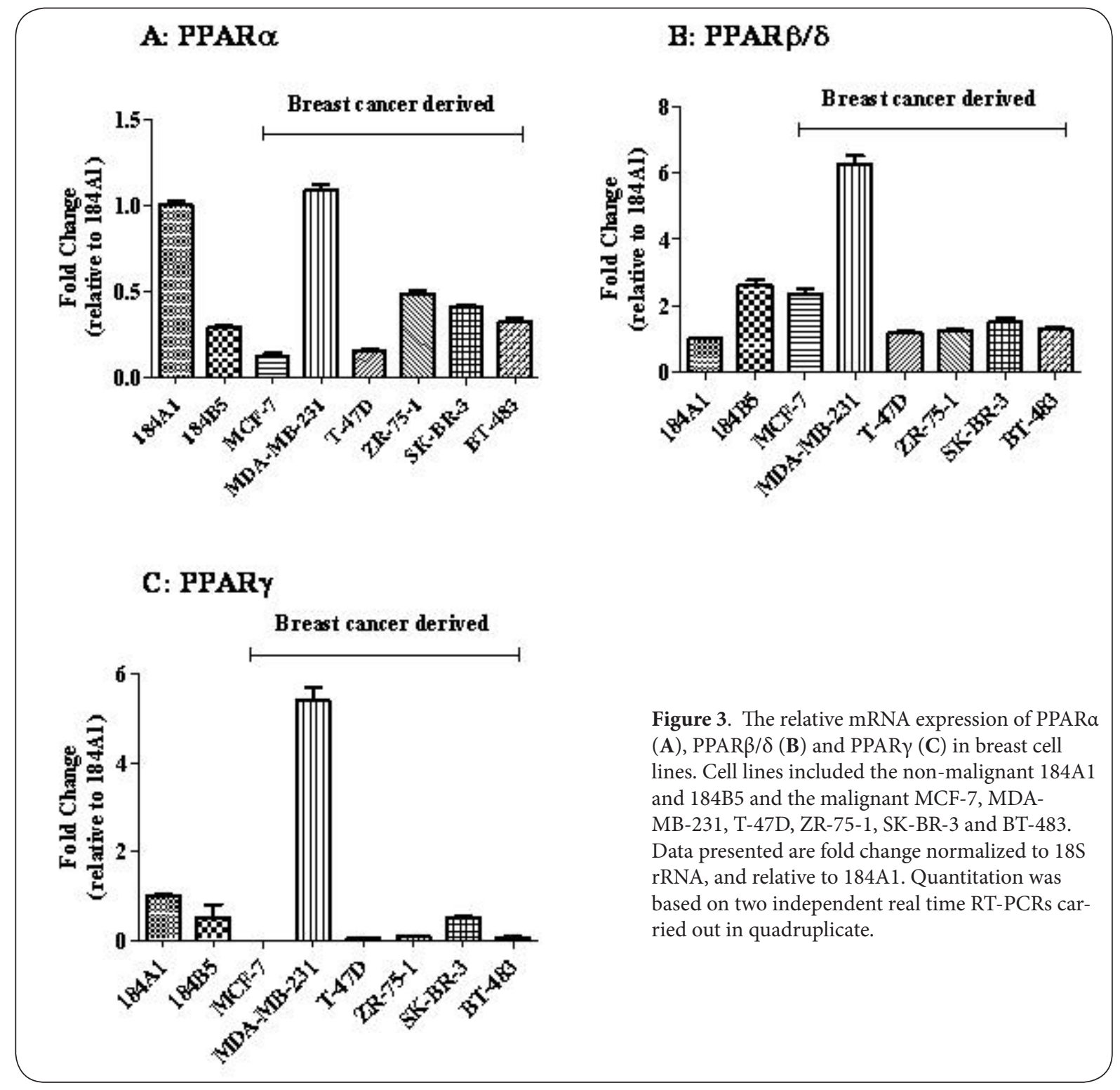

Using the transcriptional subtypes described by Perou and colleagues [16], PPARa relative expression was significantly $(P<0.05)$ higher in breast cancers of the basal subtype compared to those of the ERBB2+, luminal A or luminal B subtypes, and the expression of PPARa was associated with reduced human breast cancer patient survival $(P<0.05$, upper quartile versus others, Figure 4A). PPAR $\beta / \delta$ expression was significantly $(P<0.05)$ higher in both basal and ERBB2+ populations of breast tumors and consistent with this, intermediate and high levels of PPAR $\beta / \delta$ expression were associated with poor outcomes $(\mathrm{P}=0.0007$ ) (Figure 4B). In contrast, PPARy expression did not differ between tumor types and levels did not correlate with patient survival (Figure 4C).
Women with basal tumors have a poorer outcome than those with tumors of other subtypes [35] [33]. Many of these tumors are classified as triple negative because they lack the estrogen receptor, progesterone receptor and the HER2 receptor, predictors of successful treatment with specific molecular therapies [34]. Studies using cancer cell lines and animal models have overwhelmingly looked at PPARY and conclude that the evidence suggests an anti-tumorigenic role for PPARy in human breast cancer [36]. Despite this, a clinical trial with the PPARY agonist troglitazone failed to show a response in women with metastatic treatment-refractory breast cancer [37]. 


\section{A: PPARa}
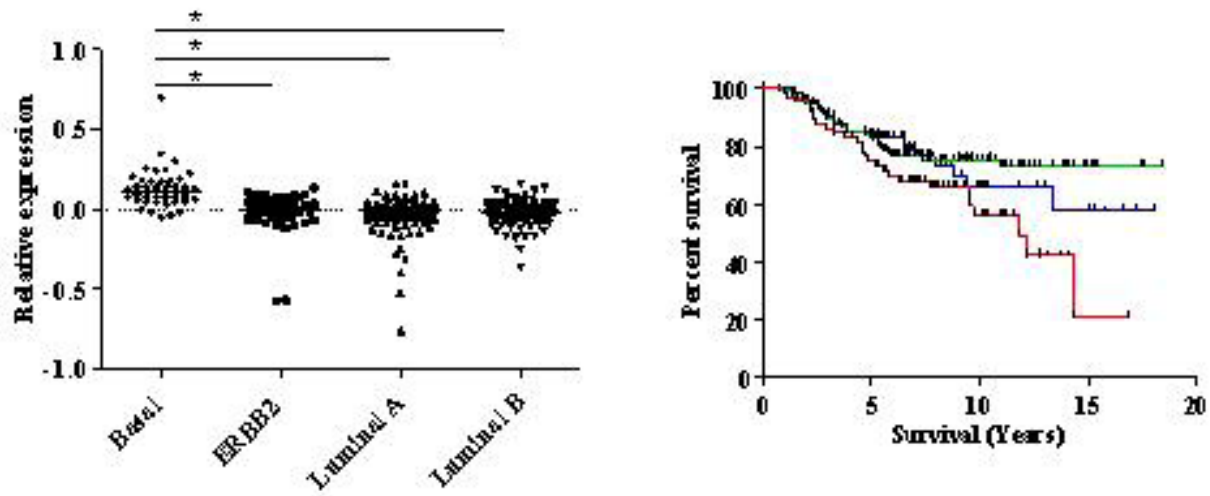

\section{B: PPAR $\beta / 5$}
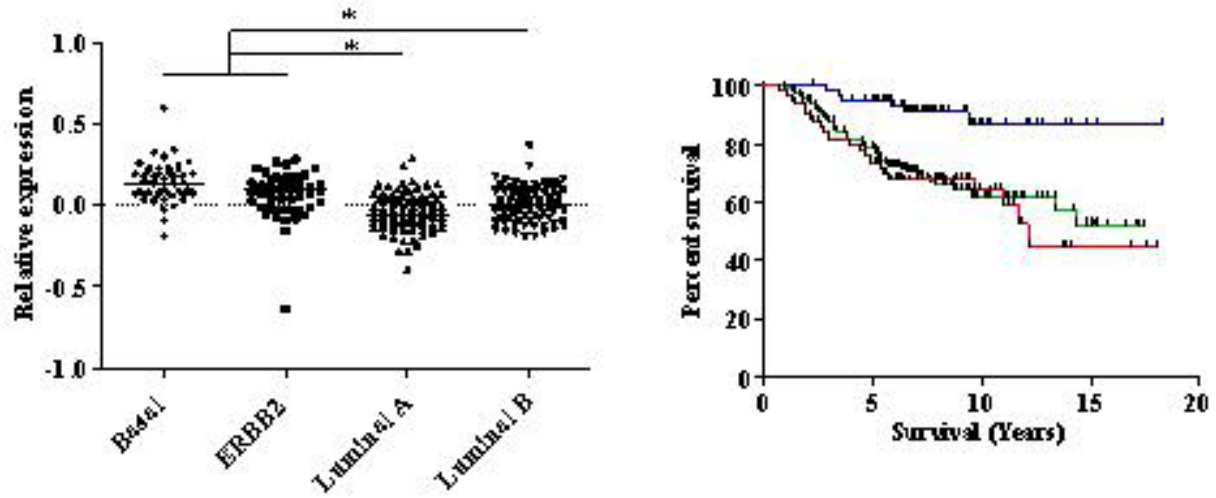

$$
\begin{aligned}
& \text { - } \mathrm{LQ}(\mathrm{r}=66) \\
& \text { - IQR }(\mathrm{r}=132) \\
& \text { - UQ } \mathrm{U}=66 \mathrm{r}=6 \mathrm{y}
\end{aligned}
$$

\section{C:PPARY}
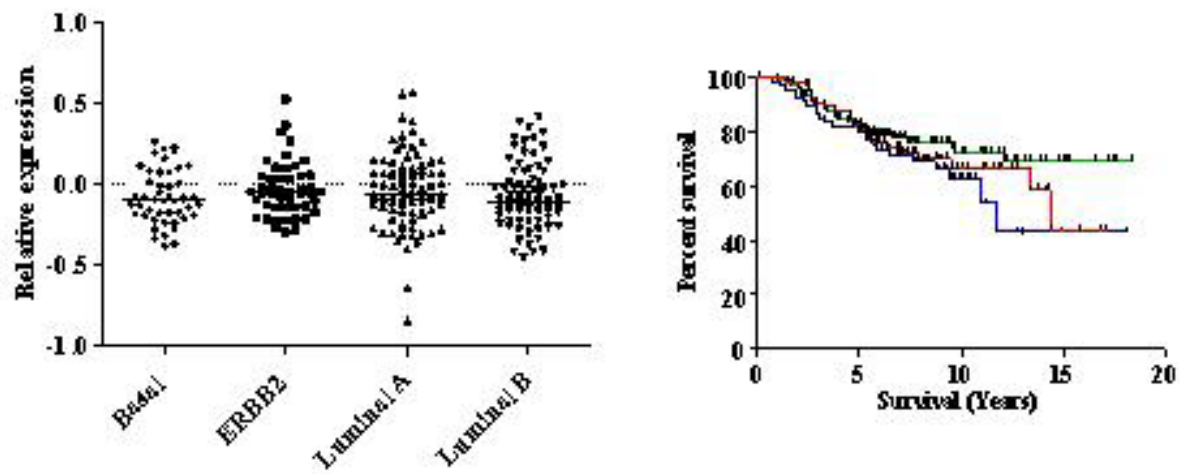

$$
\begin{aligned}
& \text { - LQ(r=66) } \\
& \text { — IQR }(\mathrm{r}=132) \\
& \text { - UQ(r=66) }
\end{aligned}
$$

Figure 4. Analysis of genes encoding PPAR $\alpha(\mathbf{A}), \operatorname{PPAR} \beta / \delta(\mathbf{B})$ and PPAR $\gamma(\mathbf{C})$ in the NKI-295 breast cancer cohort by transcriptional subtype and effect on breast cancer patient outcome. Gene expression levels in individual tumors are indicated by points, and the bars indicate the median levels in each subtype. ${ }^{\star} \mathrm{P}<0.05$ compared to basal transcriptional subtype using a one-way ANOVA with a Dunn's multiple comparison test. High levels of PPARa were associated with poorer overall survival $(\mathrm{P}=0.0151)$ and intermediate and high levels of $\mathrm{PPAR} \beta / \delta$ were associated with poorer overall survival (log-rank test for trend $\mathrm{P}<0.001$ ). 
The relationship between PPAR $\beta / \delta$ and breast cancer is not as well researched as that of PPAR $\beta / \delta$ and colon cancer [38]. Recent work with animal models has shown a pro-tumorigenic role for PPAR $\beta / \delta$ in mammary gland tumorigenicity $[28, \mathbf{3 9}$. Since the expression level of PPAR $\beta / \delta$ correlates with patient survival and there is an upregulation of PPAR $\beta / \delta$ in the basal and ERBB2 breast tumor subtypes, further work should explore tumorigenic pathways that are enriched in these subtypes. Similarly there is a paucity of data on PPARa and breast cancer, although PPARa agonists do increase proliferation in the estrogen positive and estrogen negative cells lines MCF-7 and MDA-MB-231, respectively [31].

\section{Conclusion}

In summary, the profile of PPAR subtype expression changes with mammary gland morphological and functional development suggesting differential regulation. This may help the gland fulfil its role in providing a balanced lipid profile for milk production. PPARa and PPAR $\beta / \delta$ expression also differ between breast cancer subtypes, associating with the basal-phenotype, while high expression of these PPAR subtypes correlates with poor outcome. Together this evidence indicates a potentially important role, particularly for PPARa and PPAR $\beta / \delta$, in breast epithelial homeostasis and tumorigenesis.

\section{Competing interests}

The authors declare that they have no competing interests. Authors' contributions

CF was responsible for carrying out the experiments and helping to analyse data and draft the manuscript. PAK provided the microarray data and analysis. CES provided the mouse mammary gland samples and helped with editing the manuscript. GRM was involved in study and experimental design and in data analysis and assisted with editing the manuscript. SJRT was involved in study and experimental design and in data analysis and wrote the manuscript.

\section{Acknowledgements \& funding}

Our thanks are extended to Prof Melissa Brown, The University of Queensland, for her contribution to this paper. This work was partly funded by a Cancer Council Queensland grant 569644 to SRT and GM and by Susan G. Komen for the Cure (KG100888) to PK.

\section{Author's information}

${ }^{2}$ Department of Developmental and Molecular Biology, Albert Einstein College of Medicine, New York, USA.

${ }^{3}$ The UQ Centre for Clinical Research, The University of Queensland, Brisbane, Queensland, Australia.

\section{Publication history}

Editor: E H Borge, Fox Chase Cancer Center, USA.

EIC: G.J. Peters, VU University Medical Center, Netherlands. Received: 14-May-2012 Accepted: 06-June-2012

Published: 13-July-2012

\section{References}

1. Michalik L, Auwerx J, Berger JP, Chatterjee VK, Glass CK, et al.: International Union of Pharmacology. LXI. Peroxisome ProliferatorActivated Receptors. Pharmacological Reviews 2006, 58: 726-741| Article I PubMed

2. Braissant O, Foufelle F, Scotto C, Dauca M, Wahli W: Differential expression of peroxisome proliferator-activated receptors (PPARs): tissue distribution of PPAR-alpha, -beta, and -gamma in the adult rat. Endocrinology 1996, 137: 354-366. | Article I PubMed

3. Michalik L, Wahli W: PPARs Mediate Lipid Signaling in Inflammation and Cancer. PPAR Res 2008, 2008: 134059. I Article I PubMed Abstract | PubMed Full Text

4. Reddy JK, Hashimoto T: Peroxisomal beta-oxidation and peroxisome proliferator-activated receptor alpha: an adaptive metabolic system. Annu Rev Nutr 2001, 21: 193-230. I Article I PubMed

5. Wang Y-X, Lee C-H, Tiep S, Yu RT, Ham J, et al.: Peroxisome-Proliferator-Activated Receptor [delta] Activates Fat Metabolism to Prevent Obesity. Cell 2003, 113: 159-170. | Article | PubMed

6. Tontonoz $P$, Spiegelman BM: Fat and beyond: the diverse biology of PPARgamma. Annu Rev Biochem 2008, 77: 289-312. | Article | PubMed

7. Brisken C, O'Malley B: Hormone action in the mammary gland. Cold Spring Harb Perspect Biol 2010, 2: a003178. I Article I PubMed

8. Watson C: Key stages in mammary gland development - Involution: apoptosis and tissue remodelling that convert the mammary gland from milk factory to a quiescent organ. Breast Cancer Research 2006, 8: 1-5. | Article | PubMed Abstract | PubMed Full Text

9. Neville MC, Picciano MF: Regulation of milk lipid secretion and composition. Annu Rev Nutr 1997, 17: 159-183. | Article I PubMed

10. Schwertfeger KL, McManaman JL, Palmer CA, Neville MC, Anderson SM: Expression of constitutively activated Akt in the mammary gland leads to excess lipid synthesis during pregnancy and lactation. J Lipid Res 2003, 44: 1100-1112. | Article I PubMed

11. Rudolph MC, McManaman JL, Hunter L, Phang T, Neville MC: Functional development of the mammary gland: use of expression profiling and trajectory clustering to reveal changes in gene expression during pregnancy, lactation, and involution. J Mammary Gland Biol Neoplasia 2003, 8: 287-307. I Article I PubMed

12. Faddy HM, Smart CE, Xu R, Lee GY, Kenny PA, et al.: Localization of plasma membrane and secretory calcium pumps in the mammary gland. Biochem Biophys Res Commun 2008, 369: 977-981. | Article | PubMed Abstract | PubMed Full Text

13. Feng M, Grice DM, Faddy HM, Nguyen N, Leitch S, et al.: Store-Independent Activation of Orai1 by SPCA2 in Mammary Tumors. Cell 2010, 143: 84-98. | Article | PubMed Abstract | PubMed Full Text

14. Conzen SD: Minireview: Nuclear Receptors and Breast Cancer. Mol Endocrinol 2008, 22: 2215-2228. | Article | PubMed

15. Menendez JA: Fine-tuning the lipogenic/lipolytic balance to optimize the metabolic requirements of cancer cell growth: Molecular mechanisms and therapeutic perspectives. Biochimica et Biophysica Acta (BBA) - Molecular and Cell Biology of Lipids 2010, 1801: 381-391. | Article I PubMed

16. Perou CM, Sorlie T, Eisen MB, van de Rijn M, Jeffrey SS, et al.: Molecular portraits of human breast tumours. Nature 2000, 406: 747-752. | Article I PubMed

17. Yang Z, Bagheri-Yarmand R, Balasenthil S, Hortobagyi G, Sahin AA, et al.: HER2 Regulation of Peroxisome Proliferator-activated Receptor v (PPAR $\gamma$ ) Expression and Sensitivity of Breast Cancer Cells to PPAR $\boldsymbol{\gamma}$ Ligand Therapy. Clinical Cancer Research 2003, 9: 3198-3203. | Article | PubMed

18. Lee WJ, Roberts-Thomson SJ, Monteith GR: Plasma membrane calciumATPase $\mathbf{2}$ and $\mathbf{4}$ in human breast cancer cell lines. Biochem Biophys Res Commun 2005, 337: 779-783. I Article I PubMed

19. Aung CS, Kruger WA, Poronnik P, Roberts-Thomson SJ, Monteith GR: Plasma membrane Ca2+-ATPase expression during colon cancer cell 
line differentiation. Biochem Biophys Res Commun 2007, 355: 932936. | Article | PubMed

20. van de Vijver MJ, He YD, van't Veer LJ, Dai H, Hart AA, et al.: A geneexpression signature as a predictor of survival in breast cancer. $N$ Engl J Med 2002, 347: 1999-2009. | Article | PubMed

21. Rudolph MC, Neville MC, Anderson SM: Lipid synthesis in lactation: diet and the fatty acid switch. J Mammary Gland Biol Neoplasia 2007, 12: 269-281. | Article | PubMed

22. Jain S, Pulikuri S, Zhu Y, Qi C, Kanwar YS, et al.: Differential expression of the peroxisome proliferator-activated receptor gamma (PPARgamma) and its coactivators steroid receptor coactivator-1 and PPAR-binding protein PBP in the brown fat, urinary bladder, colon, and breast of the mouse. Am J Pathol 1998, 153: 349-354. | Article | PubMed Abstract | PubMed Full Text

23. Gimble JM, Pighetti GM, Lerner MR, Wu X, Lightfoot SA, et al.: Expression of peroxisome proliferator activated receptor mRNA in normal and tumorigenic rodent mammary glands. Biochem Biophys Res Commun 1998, 253: 813-817. | Article | PubMed

24. Gutgesell A, Ringseis R, Brandsch C, StangI GI, Hirche F, et al.: Peroxisome proliferator-activated receptor alpha and enzymes of carnitine biosynthesis in the liver are down-regulated during lactation in rats. Metabolism 2009, 58: 226-232. | Article | PubMed

25. Roberts-Thomson SJ, Snyderwine EG: Characterization of peroxisome proliferator-activated receptor alpha in normal rat mammary gland and 2-amino-I-methyl-6-phenylimidazo[4, 5-b]pyridine-induced mammary gland tumors from rats fed high and low fat diets. Toxicol Lett 2000, 118: 79-86. | Article | PubMed

26. Rodriguez-Cruz M, Tovar AR, Palacios-Gonzalez B, Del Prado M, Torres $\mathrm{N}$ : Synthesis of long-chain polyunsaturated fatty acids in lactating mammary gland: role of Delta5 and Delta6 desaturases, SREBP-1, PPARalpha, and PGC-1. J Lipid Res 2006, 47: 553-560. | Article I PubMed

27. Yang $Q$, Kurotani R, Yamada A, Kimura S, Gonzalez FJ: Peroxisome proliferator-activated receptor alpha activation during pregnancy severely impairs mammary lobuloalveolar development in mice. Endocrinology 2006, 147: 4772-4780. | Article | PubMed Abstract | PubMed Full Text

28. Ghosh M, Ai Y, Narko K, Wang Z, Peters JM, et al.: PPARdelta is protumorigenic in a mouse model of COX-2-induced mammary cancer. Prostaglandins Other Lipid Mediat 2009, 88: 97-100. | Article | PubMed Abstract | PubMed Full Text

29. Wan Y, Saghatelian A, Chong LW, Zhang CL, Cravatt BF, et al.: Maternal PPAR gamma protects nursing neonates by suppressing the production of inflammatory milk. Genes Dev 2007, 21: 1895-1908. | Article | PubMed Abstract | PubMed Full Text

30. Suchanek KM, May FJ, Lee WJ, Holman NA, Roberts-Thomson SJ: Peroxisome proliferator-activated receptor beta expression in human breast epithelial cell lines of tumorigenic and non-tumorigenic origin. Int $J$ Biochem Cell Biol 2002, 34: 1051-1058. | Article | PubMed

31. Suchanek KM, May FJ, Robinson JA, Lee WJ, Holman NA, et al.: Peroxisome proliferator-activated receptor alpha in the human breast cancer cell lines MCF-7 and MDA-MB-231. Mol Carcinog 2002, 34: 165-171. | Article | PubMed

32. Neve RM, Chin K, Fridlyand J, Yeh J, Baehner FL, et al.: A collection of breast cancer cell lines for the study of functionally distinct cancer subtypes. Cancer Cell 2006, 10: 515-527. | Article | PubMed Abstract | PubMed Full Text

33. Han J, Chang H, Giricz O, Lee GY, Baehner FL, et al.: Molecular predictors of 3D morphogenesis by breast cancer cell lines in 3D culture. PLOS Comput Biol 2010, 6: e1000684. | Article | PubMed Abstract | PubMed Full Text

34. Badve S, Dabbs DJ, Schnitt SJ, Baehner FL, Decker T, et al.: Basal-like and triple-negative breast cancers: a critical review with an emphasis on the implications for pathologists and oncologists. Mod Pathol 2011, 24: 157-167. | Article | PubMed

35. Haupt B, Ro JY, Schwartz MR: Basal-like breast carcinoma: a phenotypically distinct entity. Arch Pathol Lab Med 2010, 134: 130-133. | Article I PubMed

36. Conzen SD: Minireview: nuclear receptors and breast cancer. $\mathrm{Mol}$
Endocrinol 2008, 22: 2215-2228. | Article | PubMed Abstract | PubMed Full Text

37. Burstein HJ, Demetri GD, Mueller E, Sarraf P, Spiegelman BM, et al.: Use of the peroxisome proliferator-activated receptor (PPAR) gamma ligand troglitazone as treatment for refractory breast cancer: a phase II study. Breast Cancer Res Treat 2003, 79: 391-397. | Article | PubMed

38. Aung CS, Faddy HM, Lister EJ, Monteith GR, Roberts-Thomson SJ: Isoform specific changes in PPAR alpha and beta in colon and breast cancer with differentiation. Biochem Biophys Res Commun 2006, 340 656-660. | Article | PubMed

39. Yin Y, Russell RG, Dettin LE, Bai R, Wei ZL, et al.: Peroxisome proliferator-activated receptor delta and gamma agonists differentially alter tumor differentiation and progression during mammary carcinogenesis. Cancer Res 2005, 65: 3950-3957. | Article | PubMed

\section{Citation:}

Falconer C, Kenny PA, Smart CE, Monteith GR and Roberts-Thomson SJ: Peroxisome proliferatoractivated receptor subtypes in mammary gland development and breast cancer. journal of Cancer Therapeutics and Research 2012, 1:14. http://dx.doi.org/10.7243/2049-7962-1-14 